\title{
Kant's ethics as practical philosophy: On philosophy of freedom
}

\author{
Lubomír Belás
}

\begin{abstract}
The paper focuses on some important philosophical issues of Kant's philosophical legacy, especially on Kant's thoughts on man and his acting in community with other human beings, his fellows, (Conjectural Beginning of Human History) from the aspect of morality based on moral-practical terms and categories. The field of Kant's practical-critical thoughts is not only unusually broad but also full of ideological dynamics offered in a precise and modern linguistic form. The paper claims that Kant offers his own answer for the fourth question "Was ist der Mensch" ("What is man?"), introduced in Logic (Kant, 1992, p. 538) and at the same it also introduces a historical dimension to the issue of man, included in his short writings, in a compact form.
\end{abstract}

Keywords: categorical imperative, dignity, freedom, man, moral self-realization

Act in such a way that you always treat humanity, whether in your own person or in the person of any other, never simply as a means, but always at the same time as an end.

Immanuel Kant

\section{Introduction}

The paper on Kant's ethics ${ }^{1}$ is based on a precise work with primary sources connected with functional interpretative literature, especially in German, which is also relevant for interpreting the contemporary state of the res publica. Kant's social-critical analysis connected with such issues as freedom, equality, dignity, or social contract is present in many topical philosophical discussions and disputes. The second, or human, variation of categorical imperative demanding the understanding of man mainly as an end, not as a means is also discussed. Important works dealing with this topic are e.g. the works of the German philosopher, Otrfried Höffe, or Peter Koslowski who defends ethics and its independence from social conformism. In the "Foreword" to Koslowski's work Staat und Gesellschaft bei Kant the renowned Walter Eucken-Institut stated: "No one has ever contributed to the analysis and understanding of society of free, and for themselves, responsible people as Kant did, the crucial implication of his ideas and opinions is, however, known only to a limited circle of social scientists" (Koslowski, 1985, Vorwort).

Another author who significantly contributed to the research is Kant's student, the author of the work Kants Leben und Lehre, E. Cassirer, who broadens the diapason of possible innovative philosophical procedures of his teacher in, minimally, two cases: the socialhistorical and historical-philosophical dimension of the issue by stating that "Kant still uses the language of Rousseau here, but he has gone beyond Rousseau in the systematic and methodological foundations of his ideas. While Rousseau sees all of man's history as a fall from the condition of innocence and happiness in which man lived before he entered into society and before he banded [them] into social groups, to Kant the idea of such an original state appears utopian if taken as a fact, and ambiguous and unclear if regarded as a moral

\footnotetext{
${ }^{1}$ Alexey A. Skvortsov, the Russian ethicist, claims that Kant uses the term ethics only sporadically because he understands under this term contemplations about moral sentiments and happiness so typical for Enlightenment thought. According to him, analysis of Kant's ethical ideas shows that his moral philosophy can be daringly called the second climax of ethics after Aristotle (Skvortsov, 2014, pp. 100-101).
} 
ideal. His ethics orients him toward the individual and toward the basic concept of the moral personality and its autonomy; but his view of history and its philosophy (seine geschichtliche und geschichtsphilosophische Einsicht) leads to the conviction that it is only through the medium of society that the ideal task of moral self-consciousness can find its actual empirical fulfillment [sic]. The value of society may seem negative when measured by the happiness of the individual, but this shows only that this point of view for evaluating and the standard of evaluation itself have been falsely chosen. The true criterion of this value lies not in what the social and political community accomplishes for the needs of the individual, for the security of his empirical existence, but in what it signifies as an instrument in his education into freedom" (Cassirer, 1981, pp. 223-224).

Kant's opinion, according to which human natural capacities that are directed towards the use of his reason "could be fully developed only in the species, but not in the individual" (Kant, 1991b, p. 42), has far-reaching consequences for the internal moral justification of history. In Idea for a Universal History with a Cosmopolitan Purpose Kant explains that "in the actual course of human affairs, a whole host of hardships awaits him" (Kant, 1991b, pp. 43-44) and that leads him to the conclusion that the way to a real unity of human species is possible only through fight and antinomies and only through coercion. Kant claims that nature - concerning the natural capacities of man - led man to a state where he is at a lower rank compared to other species and thus living in need and helplessness. On the other hand, it motivates him to step out of his natural limitations and isolation and by the steps of reason to leave the unity of animals and to understand that he is the end of nature. Reason, extended beyond the limits of animals, leads him to a new way of life in which the bases exist for civil constitution and public justice. After that the development of all human culture (sociability and civil security) and also inequality among people begins (Kant, 1991a, p. 230). Summarizing Kant's ideas on the development of morality in the acting and non-acting of people led by imagination, however accompanied by reason, it is possible to say that the first social bonds would not appear without his innate disposition for society, and that it was need that established and created the crucial conditions for the establishment and stabilisation of social structure. According to Kant, a social unit cannot be explained through original internal harmony of individual wills or moral-social dispositions; its being is embedded in attracting and repelling, i.e. in antagonism of powers. This contradiction is the basis and precondition of every social order.

Kant, naturally, realized the complicatedness of creating man in the historical process of leaving the state of nature and thus, reacting to Rousseau, he states: "We are cultivated to a high degree by art and science. We are civilised to the point of excess in all kinds of social courtesies and proprieties. But we are still a long way from the point where we could consider ourselves morally mature. For while the idea of morality is indeed present in culture, an application of this idea which only extends to the semblances of morality, as in love of honour and outward propriety, amounts merely to civilisation. [...] But all good enterprises which are not grafted on to a morally good attitude of mind are nothing but illusion and outwardly glittering misery" (Kant, 1991b, p. 49).

Kant also explains this issue in the work On the Common Saying: 'This May Be True in History, but it Does Not Apply in Practice', published in 1793, in which he states that "[t]he civil state, regarded purely as a lawful state, is based on the following a priori principles: 1) The freedom of every member of society as a human being. 2) The equality of each with all the others as a subject. 3) The independence of each member of a commonwealth as a citizen" (Kant, 1991c, p. 74). Kant offers an interesting solution to the principle of independence, which is closely connected with juridical process: "Anyone who has the right to vote on this legislation is a citizen (citoyen, i.e. citizen of a state, not bourgeois or citizen of a town). The only qualification required by a citizen (apart, of course, from being an adult male) is that he 
must be his own master (sui iuris), and must have some property (which can include any skill, trade, fine art or science) to support himself. In cases where he must earn his living from others, he must earn it only by selling that which is his, and not by allowing others to make use of him; for he must in the true sense of the word serve no-one but the commonwealth" (Kant, 1991c, pp. 77-78).

In this context, Jürgen Habermas speaks about a newly appearing sphere of the social. $^{2}$ Kant clearly states that reason, a priori juridical, has a "social authority" (Rossi, 2005, p. 117) and it does not take into account of any empirical purpose, e.g. blessedness. Kant also outlines the issue of possible social mobility when stating that position in society can be achieved by talent, industry and good fortune. Kant somehow completes an important task of social thought of the modern times, which is the social contract phenomenon. According to Kant, the social contract is based on a coalition of the wills of all private individuals in a nation to form a common, public will for the purposes of rightful legislation. It cannot, however be understood as a fact because "[s]uch an assumption would mean that we would first have to prove from history that some nation, whose rights and obligations have been passed down to us, did in fact perform such an act, and handed down some authentic record or legal instrument, orally or in writing, before we could regard ourselves as bound by a pre-existing civil constitution. It is in fact merely an idea of reason, which nonetheless has undoubted practical reality; for it can oblige every legislator to frame his laws in such a way that they could have been produced by the united will of a whole nation, and to regard each subject, in so far as he can claim citizenship, as if he had consented within the general will" (Kant, 1991c, p. 79).

This is the test of the rightfulness of every public law, i.e. the test of justice or injustice. A complex study of Kant's works implies a crucial philosophical task that is a convincing and especially natural justification of the question of human sociability from the point of view of creating or preserving society. It can be said that in the current debates and disputes about the search for possibilities of a return to a good life, there appears the idea of re-establishing the social contract as a possible solution to a dramatic social situation.

\section{Kant's practical philosophy: Its basic characteristics}

Kant uses the term practical intensively in the second chapter "The canon of pure reason" of the "Transcendental doctrine of method" of the Critique of Pure Reason in the first section called "On the ultimate end of the pure use of our reason" where he deals with reason's propensity of its nature to go beyond its use in experience (Kant, 1998, p. 673). He then asks whether this propensity is based only on speculative use or, on the contrary, on practical use. He then claims that a faculty of choice which can be determined independently of sensory impulses, "through motives that can only be represented by reason, is called free choice (arbitrium liberum), and everything that is connected with this, whether as grounds or consequence, is called practical" (Kant, 1998, p. 675). He continues in the following way: "Pure reason thus contains - not in its speculative use, to be sure, but yet in a certain practical use, namely the moral use - principles of the possibility of experience, namely of those actions in conformity with moral precepts which could be encountered in the history of humankind" (Kant, 1998, p. 678). The speculation of reason in its transcendental use concerns three objects: the freedom of the will, the immortality of the soul, and the existence of God. According to Kant, they are not necessary for our knowing, however, they are insistently recommended to us by our reason, so their importance must concern the practical.

\footnotetext{
2 "The "social" could be constituted as its own sphere to the degree that, on the one hand, the reproduction of life took on private forms, while, on the other hand, the private realm as a whole assumed public relevance" (Habermas, 1991, p. 127).
} 
What is practical? Narskij characterizes it in the following way: a) in broader sense of the word, practical philosophising includes: ethics, doctrine of state and right, philosophy of history, philosophy of religion, pragmatic anthropology; b) in a narrower sense of the word, the term practical reason used by Kant signifies legislative reason, i.e. reason setting the principles of moral action and behaviour of people, unifying all our ends into one (Narskij, 1976, p. 116f). If our ends are set by inclinations, it is bliss, however, Kant is interested in something else - pure (not pragmatic) laws legislated by reason a priori, laws that are not conditioned empirically, i.e. laws that command are laws of pure reason. These types of laws are represented only by moral laws and thus reason accepts them only in practice.

The first variation of critical analysis of the issue of morality can be found in the work Groundwork of The Metaphysic of Morals published in 1785. In the Preface, Kant writes: "Ancient Greek philosophy was divided into three sciences: physics, ethics, and logic. This division is perfectly suitable to the nature of the subject and there is no need to improve upon it except, perhaps, to add its principle, partly so as to insure its completeness and partly so as to be able to determine correctly the necessary subdivisions" (Kant, 1997b, p. 1). This short extract is of significant importance from the point of view of the theory of historicalphilosophical process, especially the practical dimension of philosophising. Other classic examples of $18^{\text {th }}$ century thought are: Voltaire's Philosophical Dictionary, entry "Philosopher" or Rousseau's "Profession of Faith of the Savoyard Vicar" (in Emile, or On Education).

Kant continues with an interpretatively interesting thought: "All trades, crafts, and arts have gained by the division of labour, namely when one person does not do everything but each limits himself to a certain task that differs markedly from others in the way it is to be handled, so as to be able to perform it most perfectly and with greater facility. Where work is not so differentiated and divided, where everyone is a jack-of-all-trades, there trades remain in the greatest barbarism. Whether pure philosophy in all its parts does not require its own special man might in itself be a subject not unworthy of consideration, and it might be worth asking whether the whole of this learned trade would not be better off if a warning were given to those who, in keeping with the taste of the public, are in the habit of vending the empirical mixed with the rational in all sorts of proportions unknown to themselves, who call themselves "independent thinkers," and others, who prepare the rational part only, "hairsplitters": the warning not to carry on at the same time two jobs which are very distinct in the way they are to be handled, for each of which a special talent is perhaps required, and the combination of which in one person produces only bunglers. Here, however, I ask only whether the nature of science does not require that the empirical part always be carefully separated from the rational part, and that a metaphysics of nature be put before physics proper (empirical physics) and a metaphysics of morals before practical anthropology, with metaphysics carefully cleansed of everything empirical so that we may know how much pure reason can accomplish in both cases and from what sources it draws this a priori teaching of its own - whether the latter job be carried on by all teachers of morals (whose name is legion) or only by some who feel a calling to it" (Kant, 1997b, p. 2).

Kant writes that his aim here is directed properly to moral philosophy and proposes a question: "is it not thought to be of the utmost necessity to work out for once a pure moral philosophy, completely cleansed of everything that may be only empirical and that belongs to anthropology? For, that there must be such a philosophy is clear of itself from the common idea of duty and of moral laws. Everyone must grant that a law, if it is to hold morally, that is, as a ground of an obligation, must carry with it absolute necessity; that, for example, the command "thou shalt not lie" does not hold only for human beings, as if other rational beings did not have to heed it, and so with all other moral laws properly so called; that, therefore, the ground of obligation here must not be sought in the nature of the human being or in the 
circumstances of the world in which he is placed, but a priori simply in concepts of pure reason..." (Kant, 1997b, pp. 2-3). He then claims that any other precept, which is based on principles of mere experience, can indeed be called a practical rule but never a moral law.

Kant also focuses on this issue in the "First Introduction" to the Critique of the Power of Judgement when thinking of philosophy as a system, he states that theoretical and practical philosophy exist, the first being the philosophy of nature, the other that of morals; "the first of which is also empirical, the second of which, however (since freedom absolutely cannot be an object of experience), can never contain anything other than pure principles a priori" (Kant, 2000 , p. 3). He continues in the contemplation claiming that there is a great misunderstanding about what should be held to be practical in the sense in which it deserves to be taken up into a practical philosophy. "Statesmanship and political economy, rules of good housekeeping as well as those of etiquette, precepts for good health and diet, of the soul as well as of the body (indeed why not all trades and arts?), have been believed to be able to be counted as practical philosophy, because they all contain a great many practical propositions" (Kant, 2000, p. 3). Kant says that not all practical propositions differ from theoretical ones as practical propositions exist which consider freedom under laws (Kant, 2000, p. 4).

An important moment in Kant's search and identification of the highest principle of morality is the phenomenon of good will. He writes: "It is impossible to think of anything at all in the world, or indeed even beyond it, that could be considered good without limitation except a good will. Understanding, wit, judgment and the like, whatever such talents of mind may be called, or courage, resolution, and perseverance in one's plans, as qualities of temperament, are undoubtedly good and desirable for many purposes, but they can also be extremely evil and harmful if the will which is to make use of these gifts of nature, and whose distinctive constitution is therefore called character, is not good. It is the same with gifts of fortune. Power, riches, honor [sic], even health and that complete wellbeing and satisfaction with one's condition called happiness, produce boldness and thereby often arrogance as well unless a good will is present which corrects the influence of these on the mind and, in so doing, also corrects the whole principle of action and brings it into conformity with universal ends - not to mention that an impartial rational spectator can take no delight in seeing the uninterrupted prosperity of a being graced with no feature of a pure and good will, so that a good will seems to constitute the indispensable condition even of worthiness to be happy" (Kant, 1997b, p. 7). The will is good, claims Kant, only because of its own volition, that is, it is good in itself and stands high above inclinations, usefulness, or provision.

A traditional interpretation of Kant's practical philosophy emphasises the issue of his doctrine of imperatives that, according to many readings, symbolise the core or heart of his doctrine of morals. In many contexts, Kant readers talk or write about categorical imperative as a fact of reason (Kant, 1997a, p. 177). In my opinion, these types of statements cover an important moment of Kant's thought - his reasons to use such formally strictly formulated moral-practical doctrine. In this context, Kant himself mentions the imperfection or fragility and dishonesty of human nature.

\section{Pure moral philosophy}

To some extent, the topic of this paper belongs to the German cultural-philosophical environment. It can be proven by the idea of the distinguished German Kantian thinker, Otfried Höffe, ${ }^{3}$ who wrote in the Preface to his book Kants Kritik der praktischen Vernunft:

\footnotetext{
${ }^{3}$ Otfried Höffe is a renowned German philosopher, an expert on Kantian philosophy. He deals with Kant's philosophy complexly and by his extensive philosophical view he further analyses several philosophicaltheoretical areas of historical as well as systematic character. He specialises in Enlightenment-era philosophy, morality, cosmopolitanism, philosophy of history, religion, education, law, analyses of Kant inspired ethics and at the same time he offers philosophically demanding Kantian provocations.
} 
Eine Philosophie der Freiheit that, on the peak of European Enlightenment, Immanuel Kant turns the leitmotif of his era, criticism, towards two other leitmotivs, reason and freedom. In this way he exposes the Enlightenment to radical self-criticism and on this basis he introduces his three famous questions: 1) What can I know? 2) What should I do? 3) What may I hope? Höffe continues that many interpreters of Kant's Kritik der reinen Vernunft reduce the interpretation to the first question, and although it is also about the second and third, the interpretation is very short and so it is important to deal with Kant's other works, especially texts on morals, law and state, history, religion, and pedagogy (Höffe, 2012, p. 9). This can eliminate shallow interpretations of the Enlightenment and on this basis Höffe writes about the permanent attractiveness of Immanuel Kant.

In the second part of his work Kants Kritik der praktischen Vernunft: Eine Philosophie der Freiheit Höffe concentrates on the issue of ethics as practical philosophy. In his opinion, Kant brings a real revolution to Western moral philosophy. He knows that the long-ruling principle of Eudaimonia, i.e. bliss, as well as an occasional alternative in the form of the principle of teonomy of one on God's will of the corresponding legislation, were rejected. Their place, as well as the place of other principles, e. g. Epicureanism, Stoicism, was replaced by the principle of the self-legislation of will. This revolution appeared only in the Critique of Practical Reason and was further developed in the Groundwork of the Metaphysics of Morals. Although many debates primarily concentrate on the Groundwork, it is expressed in the Critique of Practical Reason in the most distinct form. Kant formulates the meaning of his second critique in the following form: "It is therefore incumbent upon the Critique of Practical Reason as such to prevent empirically conditioned reason from presuming that it, alone and exclusively, furnishes the determining ground[s] of the will" (Kant, 1997a, p. 148). Höffe writes that in Kant's work Critique of Practical Reason, Kant's revolution of Western moral philosophy lies mainly in two parts: deconstructive and reconstructive. The first, destructive, part rejects all previous justifications of morality, or morals. While the origin of morality used to be searched for in the order of nature or commonwealth, happiness, God's will, or moral feelings before, Kant proves that all these attempts were unsuccessful (Höffe, 2012, p. 68).

Kant has two foundations for his moral-philosophical revolution. First, he wants to provide the right idea on the essence of morality, or morals. Together with Rousseau, he is convinced that the simple man already has the right concept of morals; however, he cannot revise it due to its wideness nor postulate it as a new understanding. However, he has a moral consciousness connected with the idea of unlimited obligation to enlighten himself.

Höffe writes that since John Rawls there has been a prevailing constructivism in the Anglophone interpretation of Kant's moral philosophy. Its consequence is that moral obligations are constructed by categorical imperative. Rawls legitimately sees that the process of categorical imperative is not constructed but spread. In this philosophically basic way, Kant's moral philosophy is not constructivist; it is of a character of reflexive selfenlightenment of moral consciousness (Höffe, 2012, p. 68).

Kant aims to revolutionise only the philosophy of morals, not morals itself. In this context, the formulation that everything that should be done to accomplish a task, should be realised mainly on the basis of duty. In this way, states Höffe, Kant pursues a practical end, close to a moral end, by which his ethics belongs, in an emphatic sense, to moral-practical philosophy, (Höffe, 2012, p. 69). It is important to add that the practical orientation of philosophy finds its broad use mainly in the philosophy of the Enlightenment. Voltaire, as one of the significant philosophers of his age, wrote in his Philosophical Dictionary: "there is not one [philosopher] in antiquity who has not given mankind examples of virtue and lessons in moral truths. They have all contrived to be deceived about natural philosophy; but natural philosophy is so little necessary for the conduct of life, that the philosophers had no need of it. It has taken centuries 
to learn a part of nature's laws. One day was sufficient for a wise man to learn the duties of man" (Voltaire, 1976, p. 99). His philosophical rival, Rousseau, significantly, rationalised the field of basic truths and focused mainly on the rules of acting. It is possible to state that the Enlightenment is really "critical thinking with a practical focus" (Schneiders, 1974, p. 13). It is also important to mention the degree and importance of Rousseau's influence on Kant's moral-practical thought (Belás, 2005).

Mapping Kant's various philosophical-theoretical initiatives since the first critique, morality means, for Kant, a crucial moving force which, as already seen, is closely connected with three moving forces - the Enlightenment understood as independent thinking, judicative criticism and cosmopolitanism. Thanks to these motives, Kant's philosophy is necessarily purely moral and he calls it, because it is freed from everything empirical, metaphysics of morals. He explained it clearly in the "Preface" to the Groundwork of the Metaphysics of Morals as indispensably necessary (Kant, 1997b, p. 3) from two reasons: the first lies in purely theoretical motive, "the grounds of obligation here must not be sought in the nature of the human being or in the circumstances of the world in which he is placed, but a priori simply in concepts of pure reason" (Kant, 1997b, p. 3). Kant emphasises that the metaphysics of morals has to examine the idea and the principles of a possible pure will and not the actions and conditions of human volition generally, which for the most part are drawn from psychology (Kant, 1997b, p. 4). Kant suggests that he is going to establish the metaphysics of morals one day. He characterises the present groundwork as nothing more than the search for and establishment of the supreme principle of morality (Kant, 1997b, p. 5). Kant explains the second reason why metaphysics of morals is indispensably necessary: "not merely because of a motive to speculation - for investigating the source of the practical basic principles that lie a priori in our reason - but also because morals themselves remain subject to all sorts of corruption as long as we are without that clue and supreme norm by which to appraise them correctly" (Kant, 1997b, p. 3).

Groundwork of the Metaphysics of Morals is followed by the Critique of Practical Reason that is also motivated by a moral-political aim and it is also visible in its incumbency (Obliegenheit). In this context, Höffe offers a short, however very interesting, comparative analysis of both works. Although the work Groundwork of the Metaphysics of Morals has been awarded a higher philosophical importance in history, according to Höffe, Critique of Practical Reason has a higher philosophical rank. The second critique is not only thematically richer, Kant also moves the orientation. If in the Groundworks, the categorical imperative with its various formulas and examples is in the first place, now it is autonomy, a fact of reason and sensuality in connection with practical reason, and (already discussed in the first critique) the highest good (Höffe, 2012, p. 71). Kant also wants to evaluate the unity of pure practical reason with the speculative one. In the second critique he wants to deal with this task because he believes that he will be able to solve it self-consciously and proudly. He writes: "Now, the concept of freedom, insofar as its reality is proved by an apodictic law of practical reason, constitutes the keystone of the whole structure of a system of pure reason, even of speculative reason; and all other concepts (those of God and immortality), which as mere ideas remain without support in the latter, now attach themselves to this concept and with it and by means of it get stability and objective reality, that is, their possibility is proved by this: that freedom is real, for this idea reveals itself through the moral law" (Kant, 1997a, p. 139). In the conclusion of the second critique, contemplating that what makes man something more in the world is morality, Kant may sound pathetic. And thus, he writes the often quoted text: "Two things fill the mind with ever new and increasing admiration and reverence, the more often and more steadily one reflects on them: the starry heavens above me and the moral law within me" (Kant, 1997a, p. 269). The starry heaven names the central topic of the first critique; moral law is the topic of the second critique. Kant also explains why this pathos is 
used here - he follows an existential interest: "I identify both things directly with the consciousness of my existence".

In the "Doctrine of the method of pure practical reason" Kant offers an outline of the method of founding and cultivating genuine moral disposition: "If one attends to the course of conversation in mixed companies consisting not merely of scholars and subtle reasoners but also of business people or women, one notices that their entertainment includes, besides storytelling and jesting, arguing; for storytelling, if it is to have novelty and with it interest, is soon exhausted and jesting easily becomes insipid. Now, of all arguments there are none that more excite the participation of persons who are otherwise soon bored with subtle reasoning and that bring a certain liveliness into the company than arguments about the moral worth of this or that action by which the character of some person is to be made out" (Kant, 1997a, p. 262). Kant suggests that this is the way for the human being to understand the inner freedom (Kant, 1997a, p. 268) and to release himself from the impetuous importunity of inclinations and to make use of our own reason.

\section{Acknowledgment}

This paper is part of the research project VEGA 1/0238/15 Kantove idey rozumu a súčasný svet [Kant's Ideas of Reason and Contemporary World] supported by the Ministry of Education, Science, Research and Sport of the Slovak Republic.

Lubomír Belás is a professor of systematic philosophy and director of the Institute of Philosophy at the Faculty of Arts of the University of Prešov in Prešov, Slovakia. He is the editor in chief of the philosophical journal Studia Philosophica Kantiana and specialises in philosophy of Renaissance and Modern Times, Enlightenment philosophy, Philosophy of history and philosophical-critical analysis of contemporary society, and Kant's philosophy.

\section{Corresponding author:}

Lubomír Belás, Institute of Philosophy, Faculty of Arts, University of Prešov, 17. novembra 1, SK-080 01 Prešov (Slovakia)

Email: lubomir.belas@unipo.sk

\section{References}

BELÁS, L'. (1994): Kantova filozofia dejín a „praktický rozum“ [Kant's Philosophy of History and "Practical Reason"]. In: Filozofia, 49(2), pp. 72-77.

BELÁS, L. (2005): Sociálne dôsledky Kantovej etiky [Social Consequences of Kant's Ethic]. In: Filozofia, 60(4), pp. 254-268.

CASSIRER, E. (1981): Kant's Life and Thought, trans. by J. Haden. New Haven \& London: Yale University Press.

HABERMAS, J. (1991): The Structural Transformation of the Public Sphere: An Inquiry into a Category of Bourgeois Society, trans. by T. Burger. Cambridge, MA: The MIT Press.

HÁLA, V. (1994): Impulsy Kantovy etiky. (Kant - Bolzano - Brentano). Prague: Filosofia.

HÖFFE, O. (2001): Gerechtigkeit. Eine Philosophische Einführung. München: Verlag C. H. Beck.

HÖFFE, O. (2005): Kantův kategorický imperativ jako kritérium mravnosti [Kant's Categorical Imperative as the Criterion of Morality]. In: J. Chotaš \& J. Karásek (eds.): Kanti̊v kategorický imperativ [Kant's Categorical Imperative]. Prague: OIKOYMENH, pp. 9-42.

HÖFFE, O. (2012): Kants Kritik der praktischen Vernunft. Eine Philosophie der Freiheit. München: Verlag C. H. Beck. 
KANT, I. (1991a): Conjectural Beginning of Human History. In: H. S. Reiss (ed.): Kant. Political writings (Cambridge Texts in the History of Political Thought), $2^{\text {nd }}$ ed., trans. by $\mathrm{H}$. B. Nisbet. Cambridge: Cambridge University Press, pp. 221-235.

KANT, I. (1991b): Idea for a Universal History with a Cosmopolitan Purpose. In: H. S. Reiss (ed.): Kant: Political writings, $2^{\text {nd }}$ ed., trans. by H. B. Nisbet. Cambridge: Cambridge University Press, pp. 41-53.

KANT, I. (1991c): On the Common Saying 'This May be True in Theory, but it does not Apply in Practice'. In: H. S. Reiss (ed.): Kant: Political writings, $2^{\text {nd }}$ ed., trans. by H. B. Nisbet. Cambridge: Cambridge University Press, pp. 61-92.

KANT, I. (1992): Lectures on Logic, ed. and trans. by P. Guyer \& A. W. Wood. Cambridge: Cambridge University Press.

KANT, I. (1997a): Critique of Practical Reason. In: M. J. Gregor (ed.): Kant: Practical Philosophy (The Cambridge Edition of the Works of Immanuel Kant), trans. by M. J. Gregor. Cambridge: Cambridge University Press, pp. 133-273.

KANT, I. (1997b): Groundwork of the Metaphysics of Morals (The Cambridge Edition of the Works of Immanuel Kant), ed. and trans. by M. J. Gregor. Cambridge: Cambridge University Press.

KANT, I. (1998): Critique of Pure Reason, ed. and trans. by P. Guyer \& A. W. Wood. Cambridge: Cambridge University Press.

KANT, I. (2000): Critique of the Power of Judgment, ed. and trans. by P. Guyer. Cambridge: Cambridge University Press.

KANT, I. (2005): O nejvyšším principu morálky [On the Highest Principle of Morality]. In: J. Chotaš, \& J. Karásek (eds.): Kantìv kategorický imperativ [Kant's Categorical Imperative]. Prague: OIKOYMENH, pp. 136-142.

KOSLOWSKI, P. (1985): Staat und Gesellschaft bei Kant. Tübingen: J.C.B. MOHR.

NARSKIJ, I. S. (1976): Zapadnojevropejskaja filosofia XIX. veka [Western European Philosophy of the $19^{\text {th }}$ Century]. Moscow: Vysšaja škola.

ROSSI, P. J. (2005): The Social Authority of Reason: Kant's Critique, Radical Evil, and the Destiny of Humankind. Albany: State University of New York.

ROUSSEAU, J. J. (1956): Vyznanie viery savojského vikára [Profession of Faith of the Savoyard Vicar]. In: J. J. Rousseau: Emil alebo o výchove [Emile, or On Education]. Bratislava: SPN, pp. 291-345.

SCHNEIDERS, W. (1974): Die wahre Aufklärung. Zum Selbstverständnis der deutschen Aufklärung. Freiburg \& München: Karl Aber.

SKVORTSOV, A. A. (2014): Etika [Ethics]. Moscow: Jurajt.

VOLTAIRE, F. M. A. (1976): Filozofický slovník [Philosophical Dictionary]. Bratislava: Pravda. 